\title{
Anatomical and biochemical changes during root formation in oak and apple shoots cultured in vitro *
}

\author{
MC San-José, N Vidal, A Ballester * \\ CSIC, Plant Physiology, Apartado 122, 15080 Santiago de Compostela, Spain \\ (COST Meeting, 21-23 May 1992, Dijon, France)
}

\begin{abstract}
Summary - The events leading to adventitious root formation in in vitro shoot cultures of Quercus robur L clone NL3 and Malus M9 Jork are described. Significant cellular changes were observed as early as $1-2 \mathrm{~d}$ after auxin treatment: in both species, some cambial and vascular parenchyma cells exhibited prominent nuclei and dense cytoplasm, and the first cell divisions were occasionally observed. Meristematic activity had increased by $\mathrm{d} 4$, and meristemoids became individualized 1 or $2 \mathrm{~d}$ later. Roots emerged from the shoots by $\mathrm{d} 8$ in oak and $\mathrm{d} 10$ in apple. The vascular systems of the primordium and shoot joined just before root emergence. In oak shoots, peroxidase activity was similar in auxin-treated and untreated shoots during the first $4 \mathrm{~d}$ after treatment, but subsequently increased in treated shoots and decreased in untreated shoots. In auxin-treated shoots, peroxidase activity stabilized after $\mathrm{d} 6$.
\end{abstract}

anatomy $/$ biochemistry / rooting / oak / apple tree = Malus sp

Résumé - Changements anatomiques et biochimiques se produisant durant l'enracinement de tiges de chêne et de pommier cultivées in vitro. Les événements conduisant à la formation de racines adventives sur des cultures in vitro de Quercus robur, clone NL3, et Malus M9 Jork sont décrits. Des modifications cellulaires significatives ont été observées dès 1 ou 2 jours après le traitement auxinique: dans les 2 espèces, des cellules du cambium et du parenchyme vasculaire montrent des noyaux importants et un cytoplasme dense et quelques premières divisions cellulaires sont observées. Au jour 4, l'activité méristématique augmente et des méristémoïdes s'individualisent 1 ou 2 jours après. Les racines émergent des tiges de chêne au jour 8 , et pour le pommier au jour 10. Les systèmes vasculaires du primordium et de la tige se rejoignent juste avant l'émergence de la racine. Chez les tiges de chêne, l'activité péroxidase est similaire dans les tiges traitées à l'auxine et non traitées pendant les 4 premiers jours après le traitement, puis elle augmente dans les tiges traitées, et décroît dans les tiges non traitées. Dans les tiges traitées, l'activité péroxydase se stabilise après le jour 6.

anatomie / biochimie / enracinement / chêne $/$ pommier $=$ Malus sp

\section{INTRODUCTION}

Plant regeneration in vitro provides an alternative to rooting cuttings for the propagation of woody plants. However, rooting of in vitro produced shoots is often the limiting step during propagation. Two patterns of adventitious root formation on cuttings have been recognized in both herbaceous and woody plants (Hartmann et al, 1990). One consists of the direct development of adventitious root primordia from cells associated with or in close proximity to the vascular system. The other is an indirect process in which adventitious root formation is preceded by the proliferation of undifferentiated cells, which usually starts in the parenchyma of epidermal cells; certain cells within the undifferentiated tissue then become organized and initiate an adventitious root primordium. In general, the direct pattern is found in herbaceous species and easyto-root woody species (including those examined in this study), and the indirect pattern in difficultto-root species.

A diversity of factors control morphogenesis in vitro, and no theory clearly explains all the responses observed (Halperin, 1986). As a result, current methods of in vitro rooting, like current

* Correspondence and reprints 
methods of extra vitrum rooting, are largely empirical. The more highly controlled conditions of microculture should nevertheless facilitate investigation of the biochemical, genetic and physiological bases of rooting.

One approach to decipher the mechanisms of rooting consists of the use of cytological and histological methods to estimate the physiological status of cells involved in the process of primordium formation (Molnar and Lacroix, 1972a, b). This approach has already been applied in studies on the development of adventitious roots by apple microcuttings (Hicks, 1987; Zhou et al, 1992), but we have found no references to in vitro root formation by oak shoots. In this paper, we compare the histologically observed events leading to in vitro root formation in Quercus robur clone NL3 and Malus "M9 Jork", and report the evolution of peroxidase activity during the in vitro rooting of oak shoots.

\section{MATERIALS AND METHODS}

\section{Plant material and culture conditions}

\section{Oak}

Quercus robur clone NL3 shoots were taken from stock multiplication cultures, which were subcultured every 4-wk in Gresshoff and Doy's medium (1972) supplemented with $30 \mathrm{~g} \mathrm{I}^{-1}$ sucrose, $6 \mathrm{gl}^{-1}$ Vitroagar and $0.2 \mathrm{mg} \mathrm{I}^{-1}$ 6-benzylaminopurine (BA). Four-wkold, $1.5-2.0-\mathrm{cm}$ long shoots from the stock cultures were dipped in $1 \mathrm{gl}^{-1}$ indolebutyric acid (IBA) solution for $1 \mathrm{~min}$, and then transferred to Murashige and Skoog's medium (1962) (MS) with half-strength macronutrients and no auxin.

\section{Apple}

Malus "M9 Jork" shoots were taken from stock multiplication cultures, which were subcultured every $6 \mathrm{wk}$ in a medium consisting of MS salts, $30 \mathrm{~g} \mathrm{I}^{-1}$ sorbitol, $7 \mathrm{~g}$ $\mathrm{I}^{-1}$ Sigma agar, $1 \mathrm{mg} \mathrm{I}^{-1} \mathrm{BA}$ and $0.1 \mathrm{mg} \mathrm{I}^{-1}$ IBA. Sixwk-old, $1-2-\mathrm{cm}$ long shoots from the stock cultures were rooted in Lepoivre's salt medium (Quoirin and Lepoivre, 1977) with half-strength macronutrients, MS iron and vitamins, $100 \mathrm{mg} \mathrm{l}^{-1} \mathrm{~m}$-inositol, $1 \mathrm{mg} \mathrm{l}^{-1}$ riboflavin, $100 \mathrm{mg}^{-1} \mathrm{l}^{-1}$ proline and $0.2 \mathrm{mg} \mathrm{l}^{-1}$ IBA; after 1 $w k$ in darkness in this medium, the cultures were transferred to fresh medium without auxin and standard light conditions.

Control shoots of oak and apple were treated as above, but without auxin treatment. All media were brought to $\mathrm{pH} 5.5-5.6$ before autoclaving. Cultures were kept in a growth chamber with a 16/8-h photoperiod (30 $\mu \mathrm{Em}^{-2} . \mathrm{s}^{-1}$ from cool-white fluorescent lamps) and day and night temperatures of 24 and $20^{\circ} \mathrm{C}$ respectively.

\section{Histology}

Basal $0.5-0.7 \mathrm{~cm}$ pieces of stem were collected daily up to d 10, fixed in 1:1:18 formalin/glacial acetic acid/ $50 \%$ ethanol, dehydrated, and embedded in paraffin wax (Jensen, 1962). Serial $10-\mu \mathrm{m}$ thick sections cut with a rotatory microtome were stained with safraninfast green. Starch and other insoluble polysaccharide and total protein were determined by means of the periodic acid Schiff (PAS) reaction and naphthol blue counterstain. Some appie stem segments were fixed in a $2 \%$ glutaraldehyde, $2 \%$ paraformaldehyde mixture in $0.05 \mathrm{M}$ phosphate buffer ( $\mathrm{pH} \mathrm{6.8),} \mathrm{dehydrated} \mathrm{and}$ embedded in LKB Historesin as described by Yeung and Law (1987), after which 2- $\mu \mathrm{m}$ thick sections were cut with glass knives on an ultramicrotome and stained by the PAS reaction/ naphthol blue method.

\section{Determination of peroxidase activity}

Control and treated oak shoots $(100 \mathrm{mg})$ were lyophilized and homogenized for $2 \mathrm{~min}$ in a mortar with $2 \mathrm{ml}$ phosphate buffer ( $\mathrm{pH}$ 6.1), the homogenate was centrifuged at $10000 \mathrm{~g}$ for $10 \mathrm{~min}$ at $4^{\circ} \mathrm{C}$, and the resulting supernatant filtered through a Biogel P2 column to remove phenolics. Peroxidase activity in the filtrate was determined spectrophotometrically at $25{ }^{\circ} \mathrm{C}$ by monitoring the formation of tetraguaiacol at $420 \mathrm{~nm}$.

\section{RESULTS}

\section{Oak}

\section{Morphology}

Thickening of the shoot base was first visible $5 \mathrm{~d}$ after auxin treatment, and by $\mathrm{d} 7$ the epidermis of some shoots had ruptured to reveal spongy white tissue beneath. Roots began to emerge on d 8 , and 4 wk after auxin treatment the percentage of shoots with roots had increased to 85$90 \%$, with an average of 3.4 roots per rooted shoot.

\section{Anatomy}

On $d 0$, before auxin treatment, transverse sections of NL3 shoots exhibited a practically contin- 
uous vascular ring together with a number of elements of xylem and secondary phloem. The primary phloem was surrounded by a ring of sclerenchyma formed by groups of $12-18$ thick-walled fibres separated by regions of parenchymatic tissue (fig 1a). Cortical, vascular and medullary parenchymal cells had high starch contents.

During the first 1-2d after auxin treatment, the cortex thickened somewhat and a secondary or phellogenetic cambium began to produce new cell layers in the outermost zone of the shoots. By d 2, a number of cells in the cambial zone or the vascular parenchyma, and the interfascicular spaces (fig 1b), exhibited dedifferentiation characterized by denser cytoplasm and enlarged nuclei with prominent nucleoli; some of these cells had also begun to divide on $d 2$. Mitosis increased considerably during $\mathrm{d} 3$ and 4 (fig $1 \mathrm{c}$, $1 d$ ), so that after $d 4$ groups of meristematic cells apparently corresponding to Torrey's (1966) meristemoids were observed; these cells were small and isodiametric, and had prominent nuclei staining intensely with naphthol blue (fig 1e). By d 5 or 6 , well-defined pointed root primordia had formed, and were generally located at the level of the sclerenchymal ring. During this stage, total protein content increased in the regions with active meristems, while starch and insoluble polysaccharide levels fell. The shoot epidermis was ruptured and cortical parenchymal cells became enlarged and dispersed throughout the regions (fig 1f); the presence of these parenchymal cells was responsible for the spongy macroscopic appearance of the tissue revealed by the ruptured epidermis.

The structure of the stem in control shoots remained practically identical to that observed on d 0 . Though in some control shoots, cortical parenchyma also proliferated, and sometimes broke through the epidermis, these parenchymal cells were smaller than in IBA-treated shoots.

By $d 7$, the primordia developed in auxintreated shoots had reached the cortex and the first vascular elements (tracheids) had developed. Connection between the vascular systems of root and shoot was generally complete before root emergence.

\section{Peroxidase activity}

During the first $4 \mathrm{~d}$ in rooting medium, peroxidase activity in NL3 shoots that had received auxin treatment was similar to that in untreated controls (fig 2). Subsequently, peroxidase activity increased in treated shoots, reaching a maximum of $350 \mu \mathrm{m} / \mathrm{mg}$ protein on $\mathrm{d} 6$, and then stabilized. In the untreated shoots peroxidase activity declined.

\section{Apple}

\section{Morphology}

As in oak, the basal region of the shoots became swollen 6-7 d after rooting treatment began, and small quantities of callus were formed on the cut surface. From d 10 to the end of culture $(3 \mathrm{wk})$, the percentage of auxin-treated shoots with roots rose to a final value of $65-75 \%$, with a mean of 4.5 roots per rooted shoot, whereas $<16 \%$ of untreated shoots had formed roots.

\section{Anatomy}

On d 0 , shoot sections showed a ring of collateral vascular bundles. The vascular cambium, with the cambial derivatives which developed gradually to assume the characteristics of the cellular elements of the secondary xylem and phloem, was visible. A discontinuous ring of sclerenchyma surrounded the primary phloem (fig $3 a$ ). As in oak, root formation in different shoots was not perfectly synchronous, but a similar sequence of events was apparent. The first changes, the appearance of cambial and vascular parenchyma cells with denser cytoplasm and more pronounced nuclei, were noted 1 or $2 \mathrm{~d}$ after beginning auxin treatment, at the same time as the first mitotic divisions (fig $3 b$ ). As in oak, some of these dedifferentiating cells were observed in interfascicular locations. From d 3-4 on, the number of dividing cells increased, and groups of meristematic cells (meristemoids) were formed in the phloem region near the cambium (fig 3c). By d 5-6, the meristemoids had begun to become individualized, the plane of cell divisions giving rise to the typical pointed shape of the root primordium. The growing primordia reached the sclerenchymal ring on $d 7-8$, after which they continued to grow through the cortex. Cortical parenchymal cells enlarged less and were not as dispersed as in oak, so that stem structure was better preserved. Periclinal divisions of cells in the outer layers of the primordium formed a tissue layer that subsequently gave rise to the root cap. As in oak, the connection between the vascular systems of primordium and shoot was usually complete before the 

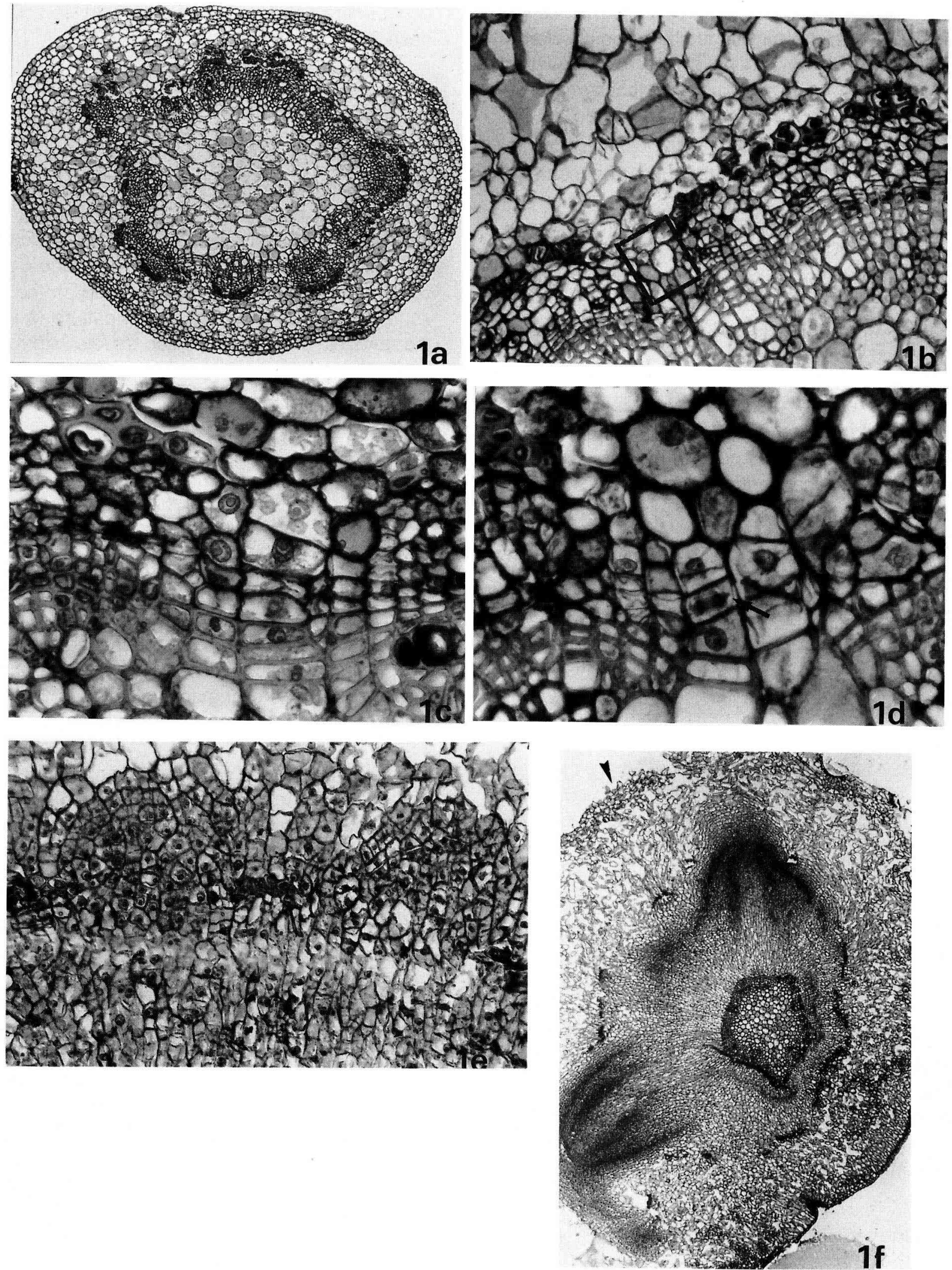

Fig 1. Transverse sections of microcuttings of oak during root formation. $\mathbf{a}, \mathbf{b}$ : Anatomy of the shoot at the time of excision; the inset in fig 16 shows the interfascicular region where some of the first mitotic divisions occur $(x 71.5, x 226)$. $\mathbf{c}, \mathbf{d}: \mathrm{d} 3$, activation of cells and (arrow) first mitotic division in the interfascicular parenchyma ( $x$ 452); e: $d 4$, meristemoids (PAS-naphthol blue stain, $x$ 178). f: $d$ 6 , root primordia and (arrow) disorganized cortex (x 28). 


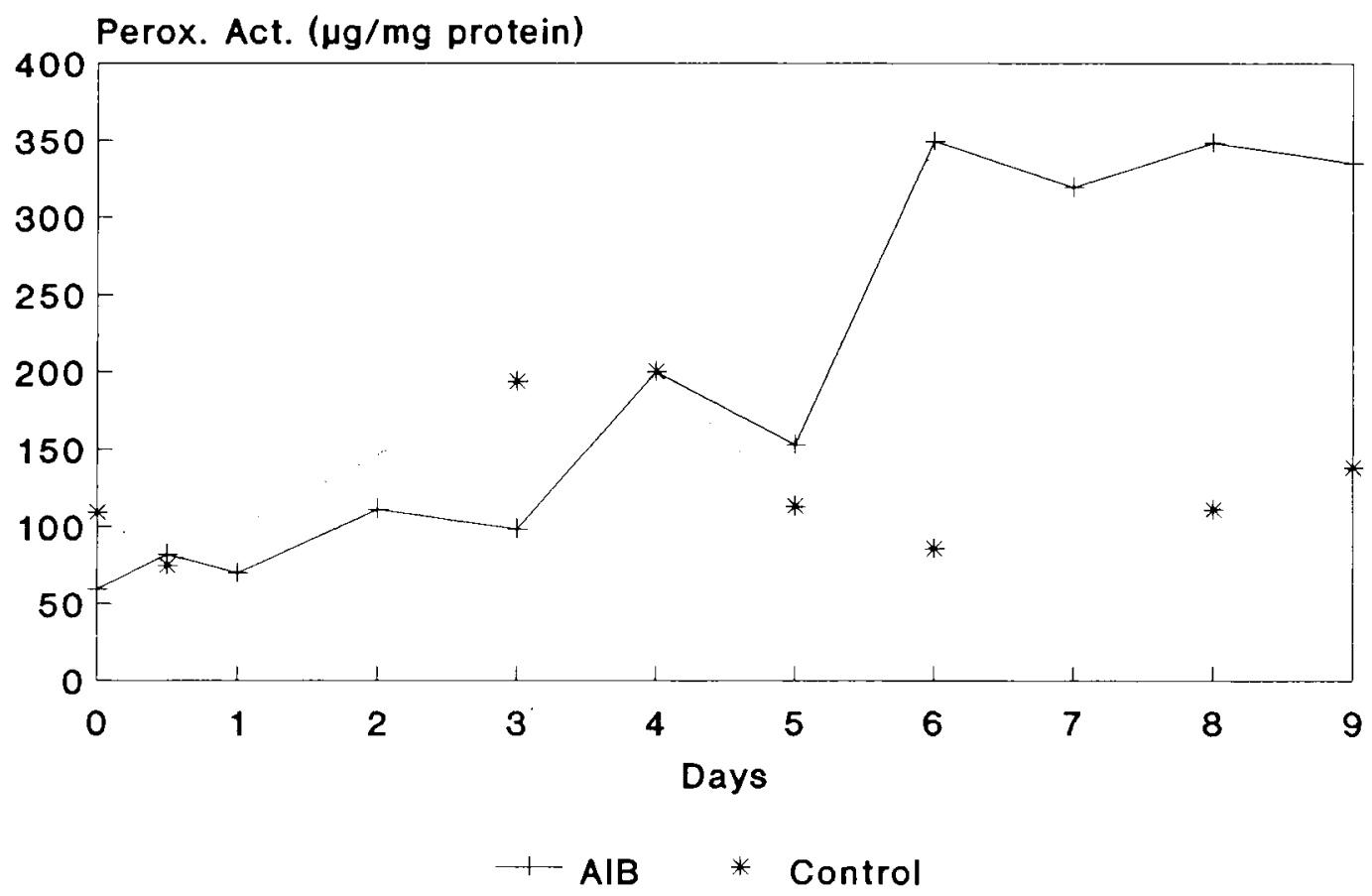

Fig 2. Peroxidase activity during in vitro rooting of Quercus robur clone NL3.

emergence of the root (fig 3d). The starch content of auxin-treated shoots fell, while total protein content increased significantly after $d 4$. The structure of untreated control shoots hardly changed during the study period.

\section{DISCUSSION AND CONCLUSION}

The anatomical events leading to adventitious root formation have been described as a series of 3 or 4 stages. Hartmann et al (1990) divided the process of rooting into dedifferentiation, the formation of root initials, the differentiation of root primordia, and finally the growth and emergence of the root. The sequence of anatomical changes observed in this work during the formation of roots in oak and apple microcuttings was very similar to that reported for the in vitro rooting of chestnut (Vieitez et al, 1981) and camellia (Samartin et al, 1986). Root initiation involves the dedifferentiation of specific cells, leading to the formation of root meristems (Hartmann et al, 1990).

An interesting question is what determines the boundaries of the organogenic domains. Thorpe (1980) suggested that the organized development leading to de novo organogenesis begins with changes in a single cell that becomes activated. The region of the tissue in which cells become activated is thought to depend in part on physiological gradients of substances entering the shoot from the medium (Ross et al, 1973). In a study on Hedera helix, Geneve (1991) coined the term "competent root-forming cells" (CRFC) to describe the cells involved in direct initiation of root primodia; such cells are considered to be competent to form adventitious roots in the presence of an exogenously applied or endogenously accumulating inducer (usually auxin) which initiates polar cell divisions eventually leading directly to the formation of a root primordium. Tripepi et al (1983) provided evidence concerning early activation events in CRFCs. They showed that throughout the hypocotyl of mung bean cuttings treated with radiolabelled uridine or thymidine there was an increase in both DNA and RNA synthesis in specific cells associated with sites of potential formation of root primordia. Species exhibiting the direct root formation pattern are supposed to possess CRFCs.

In the oak and apple clones studied in our work, the first signs of the formation of adventitious roots were the appearance of larger nuclei and denser cytoplasm in cells located in and adjacent to the vascular bundles near the cambium. Similar findings were reported by Hicks (1987), who observed that in apple the tissues in and around the vascular strands became activated, and that meristemoids formed from certain of these cell populations lying outside the xylem. 

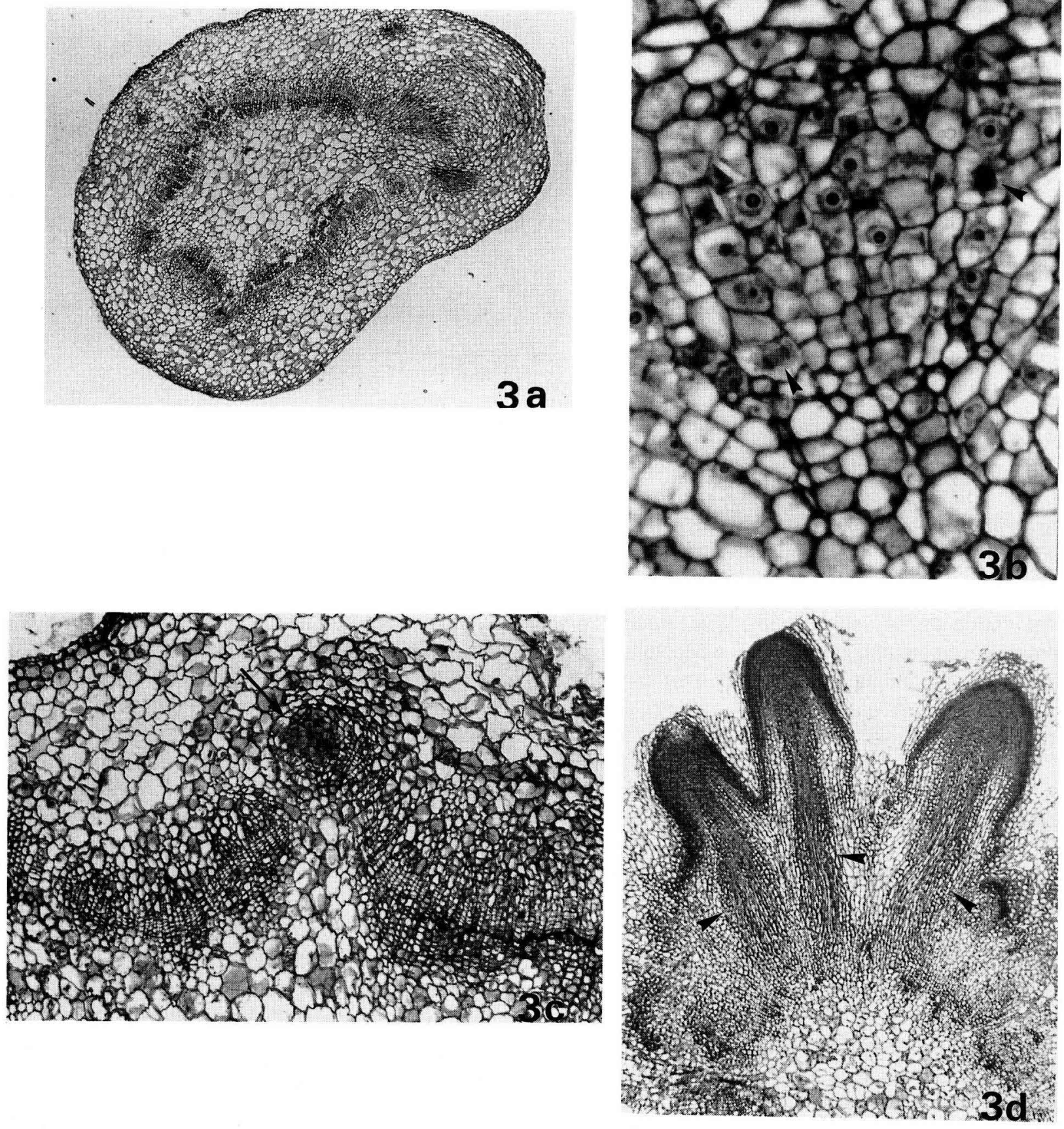

Fig 3. Transverse sections of microcuttings of apple during root formation. $\mathbf{a}$ : anatomy of the shoot at time of excision ( $x 31)$. $\mathbf{b}: \mathrm{d} 3$, activation of cells and (arrow) first mitotic divisions in cambial and phloem regions ( $x$ 492). c : $d 4$, meristemoid (arrow) ( $x 77$ ). $d$ : d10, root emerging from the shoot; note the vascular connexions (arrow) between the main vascular system of the shoot and that of the roots $(\times 39)$.

Again, Zhou et al (1992) reported that in microcuttings of the easy-to-root Malus clone M26, adventitious roots were initiated directly in cambial derivatives (whereas in the difficult-to-root clone

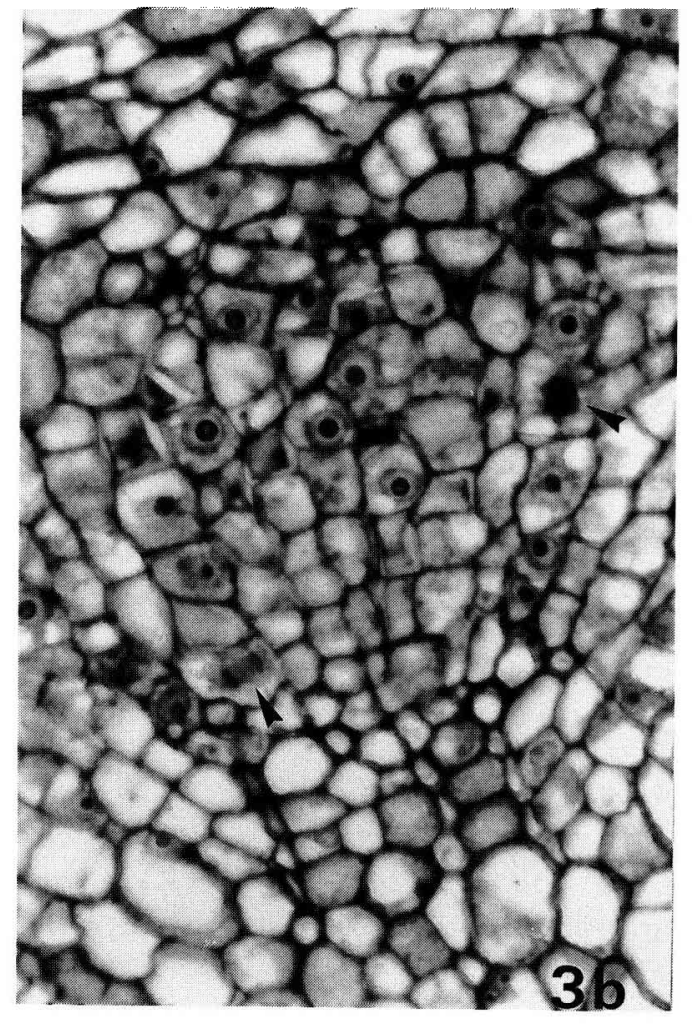


In this study, we found that changes in peroxidase activity during the in vitro rooting of oak shoots exhibited a pattern partly similar to those reported for other woody species. We observed an increase during the rooting treatment but not the characteristic decrease, probably due to measuring peroxidase activity in purified extracts. According to some authors (Moncousin and Gaspar, 1983; Moncousin et al, 1988; Gaspar, 1989), the peroxidase activity peak marks the end of the "induction" stage of root formation. In Sequoiadendron giganteum the peroxidase peak is reached on $d$ 17, when the meristemoids are formed (Berthon et al, 1987); in oak, the maximum peroxidase activity is reached on $d 6$, when root primordia have already been formed (apparently a couple of days after the formation of meristemoids).

Thus intense mitotic activity, coupled to elaborate metabolic changes, appears to be an essential prerequisite for root formation (Haissig, 1986; Torrey, 1986). Such findings are in keeping with the hypothesis that the initiation of organized development in vitro involved a shift in metabolism both before and during the actual development process (Thorpe, 1980). The identification of these changes would lead to a better understanding of the formation of adventitious roots.

\section{ACKNOWLEDGMENTS}

We thank Ir BPAM Kunneman (COWT, Lisse, The Netherlands) for supplying in vitro apple shoots through the COST 87 Root Regeneration Working Group. Partial financial support of this work by the EEC under ECLAIR Project AGRE-0067 is also gratefully acknowledged.

\section{REFERENCES}

Berthon JT, Boyer N, Gaspar T (1987) Sequential rooting media and rooting capacity of Sequoiadendron giganteum. Peroxidase activity as a marker. Plant Cell Rep 6, 341-344

Gaspar T (1989) Root formation, vitrification, calli: changing concepts. News Bull Br Plant Growth Regul Group 11, 1-7

Geneve RL (1991) Patterns of adventitious root formation in English ivy. J Plant Growth Regul 10, 215220

Gresshoff PM, Doy CH (1972) Development and differentiation of haploid Lycopersicon esculentum. Planta 107, 161-170

Haissig BE (1986) Metabolic processes in adventitious rooting of cuttings. In: New Root Formation in
Plants and Cuttings (Jackson MB, ed) Martinus Nijhoff Publ, The Netherlands, 141-190

Halperin W (1986) Attainment and retention of morphogenetic capacity in vitro. In: Cell Culture and Somatic Cell Genetics of Plants, Plant Regeneration and Genetic Variability (Vasil IK, ed) Academic Press, Orlando, FL, 3-47

Hartmann HT, Kester DE, Davies FJ (1990) Plant Propagation: Principles and Practices. Prentice Hall, Englewood Cliffs, $\mathrm{NJ}$

Hicks GS (1987) Adventitious rooting of apple microcuttings in vitro, an anatomical study. Can J Bot 65, 1913-1920

Jensen WA (1962) Botanical Histochemistry. WH Freeman and Co, San Francisco, CA

Molnar JM, Lacroix LJ (1972a) Studies of the rooting of cuttings of Hydrangea macrophylla: enzyme changes. Can J Bot 50, 315-322

Molnar JM, Lacroix LJ (1972b) Studies of the rooting of cuttings of Hydrangea macrophylla: DNA and proteins changes. Can J Bot 50, 387-392

Moncousin C, Gaspar T (1983) Peroxidases as a marker for rooting improvement of Cynara scolymus $L$ cultured in vitro. Biochem Physiol Pflanz 178, 263-271

Moncousin C, Favre JM, Gaspar T (1989) Changes in peroxidase activity and endogenous IAA levels during adventitious rooting in vine cuttings. In: Physiology and Biochemistry of Auxins in Plants (Kutacek $\mathrm{M}$, Bandurski RS, Krekule J, eds) Academia, Prague, 331-337

Murashige T, Skoog F (1962) A revised medium for rapid growth and bioassays with tobacco tissue culture. Physiol Plant 15, 473-497

Quoirin M, Lepoivre P (1977) Étude de milieux adaptés aux cultures in vitro de Prunus. Acta Hortic 78, 437-442

Ross MK, Thorpe TA, Costerton JW (1973) Ultrastructural aspects of shoot initiation in tobacco callus cultures. Am J Bot 60, 788-795

Samartin A, Vieitez AM, Vieitez E (1986) Rooting of tissue cultured camellias. J Hortic Sci61, 113-120

Thorpe TA (1980) Organogenesis in vitro: structural, physiological and biochemical aspects. In: Perspectives in Plant Cell and Tissue Culture (Vasil IK, ed) Academic Press, NY, 71-111

Torrey JA (1966) The initiation of organized development in plants. Adv Morphog 5, 39-91

Torrey JG (1986) Endogenous and exogenous influences on the regulation of lateral root formation. $I n$ : New Root Formation in Plants and Cuttings (Jackson MB, ed) Martinus Nijhoff Publishers, The Netherlands, 31-66

Triperi RR, Heuser CW, Shannon JC (1983) Incorporation of tritiated thymidine and uridine into adventitious root initial cell of Vigna radiata. J Am Soc Hortic Sci 108, 469-474

Vieitez AM, Vieitez ML, Ballester A (1981) In vitro chestnut regeneration. Anatomical and chemical changes during the rooting process. Coll Int Culture 
In Vitro des Essences Forestières. IUFROAFOCEL, France, 149-152

Yeung EC, Law SK (1987) Serial sectioning techniques for a modified LKB Historesin. Stain Technol $62,147-153$
Zhou J, Wu H, Collet GF (1992) Histological study of initiation and development in vitro of adventitious roots in minicuttings of apple rootstocks of M26 and EMLA 9. Physiol Plant 84, 433-440 